\title{
Resection of Clavicle
}

National Cancer Institute

\section{Source}

National Cancer Institute. Resection of Clavicle. NCI Thesaurus. Code C51789.

Surgical removal of part or all of the clavicle. 